\title{
PENGEMBANGAN PERANGKAT PEMBELAJARAN IPA MODEL INKUIRI TERBIMBING DENGAN STRATEGI MOTIVASI ARCS UNTUK MENINGKATKAN HASIL BELAJAR SISWA SMP
}

\author{
Asnita $^{1)}$, Wasis $^{2)}$, Soetjipto $^{3)}$ \\ ${ }^{1)}$ Mahasiswa Program Studi Pendidikan Sains, Program Pascasarjana Universitas Negeri Surabaya \\ ${ }^{2), 3)}$ Dosen Pascasarjana Prodi Pendidikan Sains Universitas Negeri Surabaya \\ E-mail: asnita_fisika2013@yahoo.com
}

\begin{abstract}
Abstrak: Penelitian ini bertujuan untuk menghasilkan perangkat pembelajaran IPA model inkuiri terbimbing dengan strategi motivasi ARCS yang layak untuk meningkatkan hasil belajar siswa. Pengembangan perangkat pembelajaran mengikuti rancangan model 4-D dan diujicobakan di kelas VII SMPN 17 Kendari semester genap tahun ajaran 2014/2015 dengan desain One-Group Pretest-Posttest design. Pengumpulan data menggunakan metode validasi, observasi, tes, dan angket. Teknik analisis data menggunakan analisis deskriptif kualitatif. Hasil penelitian ini menunjukkan: 1) Perangkat pembelajaran yang dikembangkan valid; 2) Semua rencana pembelajaran terlaksana dengan kategori baik; 3) motivasi siswa dengan kategori baik terhadap pembelajaran; 4) hasil belajar siswa mengalami peningkatan dengan skor $N$-gain berkategori tinggi. Berdasarkan hasil penelitian tersebut dapat disimpulkan bahwa perangkat pembelajaran model inkuiri terbimbing dengan strategi motivasi ARCS yang dikembangkan layak untuk meningkatkan hasil belajar siswa SMP.
\end{abstract}

Kata kunci: Pengembangan Perangkat Pembelajaran, Inkuiri Terbimbing, Strategi Motivasi ARCS, Hasil Belajar.

\begin{abstract}
This research aimed to produce learning science materials using guided inquiry model with the ARCS motivational strategies that feasible to improve students' learning achievement. The development of learning materials used 4D model design and it was tested in the VII grade of SMPN 17 Kendari, even semester in academic year of 2014/2015 with One-Group Pretest-Posttest Design. The data collections used validation, observation, test, and quetionnaires methods. The data analysis techniques used qualitative descriptive analysis. The results of this research showed: 1) the developed teaching and learning materials were valid with good category; 2) learning implementation was conducted; 3) students' motivation after conducting the learning has a good category and 4) students' learning achievement has increased with high category gain score. Based on the results, it could be concluded that the guided inquiry learning models that integrate the ARCS motivational strategies were feasible to improve the learning achievement of junior high school students.
\end{abstract}

Keywords: Development of Learning Materials, Guided Inquiry, ARCS Motivation Strategy, LearningAchievement.

\section{PENDAHULUAN}

Proses pembelajaran pada satuan pendidikan diselenggarakan secara interaktif, inspiratif, menyenangkan, menantang, dan memotivasi siswa untuk berpartisipasi aktif serta memberikan ruang yang cukup bagi prakarsa, kreativitas, dan kemandirian sesuai dengan bakat, minat, dan perkembangan fisik serta psikologis siswa. Pembelajaran diarahkan untuk mendorong siswa mencari tahu dari berbagai sumber observasi, mampu merumuskan masalah (menanya) bukan hanya menyelesaikan masalah. Pembelajaran diarahkan untuk melatih siswa berpikir analitis (pengambilan keputusan) bukan berpikir mekanistis (rutin) serta mampu kerjasama dan kolaborasi dalam menyelesaikan masalah.

Kurikulum 2013 menerapkan pendekatan saintifik dalam pembelajaran dan penilaian otentik dalam pembelajaran. Pendekatan ilmiah (scientific), perlu diterapkan untuk memperkuat pembelajaran berbasis penemuan/penyelidikan (discovery/inquiry learning) (Sumber, Dokumen Kurikulum 2013). Mata pelajaran IPA di SMP dilakukan dengan konsep integrative science. Maka dari itu Agar pemahaman siswa terhadap hakikat IPA menjadi utuh, baik sebagai proses maupun sebagai produk maka dalam pembelajaran IPA, siswa harus memperoleh pengalaman langsung, sehingga dapat menambah kekuatan untuk menerima, menyimpan, dan menerapkan konsep yang telah dipelajarinya agar siswa terlatih untuk dapat menemukan sendiri berbagai konsep yang dipelajari secara menyeluruh (holistik), bermakna, autentik, dan aktif. Proses pembelajaran IPA bukan hanya memahami konsep-konsep IPA itu sendiri, tetapi juga mengajarkan siswa berpikir konstruktif. 
Berdasarkan observasi di SMPN 17 Kendari, dari hasil diskusi, peneliti mendapat informasi bahwa dalam proses pembelajaran untuk materi suhu dan kalor dalam penyampaian materi, guru hanya menggunakan metode ceramah artinya guru hanya memfokuskan pada penyampaian materi, alat-alat lab kurang dimanfaatkan oleh guru agar pembelajaran lebih berpariasi sehingga memberikan kesempatan bagi siswa untuk menemukan sendiri konsep-konsep IPA berdasarkan hasil percobaan/penyelidikan yang dilakukan secara sederhana. Siswa disibukkan mencatat materi yang disampaikan oleh guru sehingga kondisi kelas menjadi pasif, guru menjadi pusat pembelajaran sedangkan siswa hanya aktif sebagai pendengar dan mencatat informasi yang disampaikan oleh guru. Pengajaran sains yang terbatas pada nilai produk, siswa lebih banyak menghapal dan mengingat pada materi yang disajikan, sehingga mengakibatkan pembelajaran membosankan dan tidak menarik bagi siswa. Kondisi kelas yang membosankan akan menurunkan atau bahkan menghilangkan motivasi belajar siswa, terlebih lagi pembelajaran IPA dianggap pelajaran yang sulit bagi siswa sehingga siswa kurang antusias untuk mempelajarinya sehingga keaktifan siswa dalam kelas menurun. Permasalahan yang lain adalah keterbatasan guru dalam mengembangkan perangkat pembelajaran yang dapat membuat siswa lebih aktif untuk memotivasi siswa dalam pembelajaran sehingga diharapkan dapat meningkatkan hasil belajar siswa. Proses pembelajaran yang dilakukan masih terfokus pada penguasaan materi pembelajaran sedangkan penguasaan sikap dan keterampilan dalam belajar belum mendapat perhatian yang cukup. Guru belum maksimal melaksanakan pembelajaran konstruktivis, sehingga pembelajaran kurang memberikann motivasi pada siswa untuk terlibat aktif dalam proses pembelajaran di kelas.

Hasil observasi tersebut tidak sesuai dengan Permendikbud Nomor 65 Tahun 2013 tentang Standar Proses Pendidikan yang menghendaki proses pembelajaran yang mengedepankan pendekatan ilmiah (scientivic approach). Pendekatan ilmiah dalam Kurikulum 2013 mengedepankan peran aktif siswa dalam membangun pengetahuannya sendiri, dan peran guru sebagai fasilitator dan mitra belajar siswa yang menyediakan layanan dan kemudahan belajar (facilitate learning) bagi seluruh siswa (Mulyasa, 2013). Kompetensi siswa pada ranah sikap, pengetahuan dan keterampilan harus ditumbuhkan dalam pembelajaran IPA (Widodo, 2014).

Salah satu model yang sesuai dengan pendekatan ilmiah yang mampu memotivasi siswa untuk meningkatkan hasil belajar siswa, agar siswa lebih terampil dalam menyelesaikan masalah adalah model inkuiri terbimbing dengan strategi motivasi ARCS, sehingga dalam penelitian ini peneliti mencoba mengembangkan perangkat pembelajaran IPA model inkuiri terbimbing dengan strategi motivasi ARCS yang diharapkan dapat meotivasi siswa untuk belajar sehingga akan berdampak pada hasil belajar yang lebih baik.

Penelitian ini menggunakan model inkuiri terbimbing karena pembelajaran ini digunakan untuk siswa yang belum berpengalaman belajar yaitu siswa SMP serta siswa masih perlu banyak bimbingan dalam pembelajarannya. Menurut Banchi \& Bell (2008) menyatakan bahwa guru harus memulai pembelajaran penyelidikan pada tingkat yang lebih rendah, agar siswa secara efektif mengembangkan keterampilan penyelidikan.

Model pembelajaran inkuiri merupakan kegiatan pembelajaran yang menekankan pada proses berpikir secara kritis serta analitis untuk dapat mencari tahu dan menemukan sendiri jawaban dari suatu masalah (Sanjaya, 2011). Menurut Straits \& Wilke (dalam Jufri, 2013) pembelajaran inkuiri merupakan pembelajaran kontruktivisme yang menekankan pada proses keaktifan siswa. Keunggulan pembelajaran inkuiri Sanjaya (2006) bahwa pembelajaran inkuiri dapat membuat pembelajaran lebih bermakna dan dapat mengembangkan aspek kognitif, afektif, dan psikomotor siswa.

Salah satu hambatan yang sering ditemui dalam pembelajaran model inkuiri terbimbing yaitu pada siswa yang pasif, oleh karena itu diperlukan suatu motivasi yang lebih terhadap siswa yang pasif dalam pembelajaran (dalam Ong dan Borich, 2006). Motivasi penting dalam pembelajaran karena motivasi merupakan dorongan yang terdapat pada diri seseorang dalam berusaha mengadakan perubahan tingkah laku agar lebih baik untuk memenuhi kebutuhannya (Uno, 2012). Menurut Baron (1992) dan Slavin (1997) (dalam Kardi, 2012) motivasi merupakan suatu proses internal untuk mengaktifkan, mengarahkan serta mempertahankan tingkah laku dalam waktu tertentu.

Siswa termotivasi untuk belajar akan menggunakan proses kognitif yang lebih tinggi untuk mempelajari materi tersebut sehingga akan menyerap dan mengendapkan materi tersebut dengan lebih baik serta siswa yang termotivasi dalam belajar akan unggul diberbagai aktivitas kelas akan menunjukkan kecenderungan siswa yang sukses di kelas Gottfried, 1990; Schiefele, Krapp \& Winteler, 1992; Wahlberg \& Uguroglu, 1980 (dalam Ormrod, 2008). pembelajaran Inkuiri terbimbing merupakan salah satu cara belajar yang dapat memotivasi siswa untuk belajar dengan memberikan kesempatan dan bimbingan kepada siswa untuk mengkontruksi pengetahuan siswa sendiri dan mengembangkan pemahaman yang mendalam (Kuhlthau, 2007). Keller 
(1987) memperkenalkan suatu strategi motivasi ARCS (Attention, Relevance, Confidence, Satisfaction). Keller menyatakan bahwa strategi moivasi ARCS merupakan salah satu cara yang dapat digunakan guru untuk meningkatkan motivasi, dan aktivitas siswa dalam belajar. Strategi Motivasi ARCS dapat: (1) meningkatkan perhatian siswa terhadap materi pembelajaran, (2) menghubungkan materi dengan manfaatnya dalam kehidupan sehari-hari, meningkatkan kepercayaan siswa terhadap materi yang diberikan guru, (4) dapat mewujudkan kepuasaan siswa dalam hal proses pembelajaran (Keller, 1987). Peran guru yang optimal dalam pembelajaran melalui model inkuiri terbimbing dengan strategi motivasi ARCS akan membuat siswa termotivasi mengembangkan kemampuan dan kreativitas belajarnya, juga akan merasa senang dan bertanggung jawab dalam menyelesaikan tugas-tugas yang diberikan. Keterlibatan guru menciptakan komunitas kelas yang hangat dan penuh perhatian dengan banyaknya praktek motivasi yang sportif, dan selalu menunjukkan perencanaan yang baik mengakibatkan hasil kerja mencapai tingkat yang baik (Arends, 2008).

Hasil penelitian Mukhlasin di SMP Muhammadiyah

15 Surabaya (2011) Penerapan Strategi motivasi ARCS menunjukan bahwa, hasil belajar siswa baik produk, proses, maupun psikomotor secara klasikal telah mencapai ketuntasan belajar serta motivasi dan minat siswa pada awalnya berada pada kategori cukup baik kemudian meningkat menjadi baik. Wulandari, dkk (2013), menyimpulkan bahwa Pembelajaran praktikum berbasis inkuiri terbimbing dapat menarik minat serta motivasi belajar siswa. Penemuan Astleitner, H. \& Koller, M. (2006), menyimpulkan bahwa strategi ARCS dapat meningkatkan efektivitas motivasi dan pembelajaran kognitif.

Salah satu pokok bahasan IPA SMP yang tercantum dalam Kurikulum 2013 adalah Suhu dan Kalor yang diajarkan pada siswa SMP kelas VII semester Genap, pada Kompetensi Dasar 3.7 Memahami konsep suhu, pemuaian, kalor, perpindahan kalor, dan penerapannya dalam mekanisme menjaga kestabilan suhu tubuh pada manusia dan hewan serta dalam kehidupan sehari-hari. Kompetensi dasar ini akan dijabarkan dalam beberapa indikator. Perangkat pembelajaran yang menggunakan model pembelajaran inkuiri terbimbing dengan strategi motivasi ARCS belum pernah dikembangkan oleh guru di SMP Negeri 17 Kendari. Peneliti mencoba mengembangkan perangkat pembelajaran IPA model inkuiri terbimbing dengan strategi motivasi ARCS untuk meningkatkan hasil belajar siswa SMP pada materi suhu dan kalor. Penemuan ini sesuai dengan penelitian Wagman (2005), Colakoglu dan Akdemir (2010) bahwa inkuiri dapat mendukung motivasi siswa.
Adapun untuk melaksanakan pembelajaran tersebut, untuk mempermudah dan membantu siswa dalam proses belajar maka peneliti berupaya mengembangkan sebuah perangkat pembelajaran yang terdiri dari, Rencana Pelaksanaan Pembelajaran (RPP), Lembar Kegiatan Siswa (LKS), Buku Ajar Siswa (BAS), instrumen penilaian. Pembuatan perangkat pembelajaran tersebut disesuaikan dengan kemampuan siswa, kondisi lingkungan sekolah, dan sesuai tuntutan Kurikulum 2013. Perangkat pembelajaran yang dibuat disesuaikan dengan model pembelajaran yang dipilih yaitu inkuiri terbimbing dan dipaduhkan dengan strategi motivasi ARCS, yang diharapkan dapat membangkitkkan motivasi siswa dan memaksimalkan hasil belajar siswa.

Berdasarkan uraian di atas maka peneliti akan melakukan penelitian dengan judul Pengembangan Perangkat Pembelajaran IPA Model Inkuiri Terbimbing dengan Strategi Motivasi ARCS untuk Meningkatkan Hasil Belajar Siswa SMP. Rumusan masalah dalam penelitian ini adalah "Bagaimanakah kelayakan perangkat pembelajaran yang dikembangkan berdasarkan model inkuiri terbimbing dengan strategi motivasi ARCS untuk meningkatkan hasil belajar siswa SMP"? (1) Bagaimana validitas perangkat pembelajaran yang telah dikembangkan? Bagaimana keterlaksanaan Rencana Pelaksanaan Pembelajaran (RPP) selama proses pembelajaran dengan menggunakan perangkat pembelajaran yang dikembangkan? (3) Bagaimana hasil belajar siswa setelah mengikuti kegiatan pembelajaran IPA materi suhu dan kalor? (4) Bagaimana motivasi siswa setelah mengikuti pembelajaran IPA yang menggunakan model inkuiri terbimbing dengan strategi motivasi ARCS?

Berdasarkan permasalahan di atas, maka tujuan penelitian ini adalah untuk mengetahui kelayakan perangkat pembelajaran IPA model inkuiri terbimbing dengan strategi motivasi ARCS untuk meningkatkan hasil belajar siswa SMP. Tujuan tersebut dapat dicapai dengan mememenuhi tujuan-tujuan sebagai berikut: (1) Mendeskripsikan validitas perangkat pembelajaran yang dikembangkan (2) Mendeskripsikan Keterlaksanaan Rencana Pelaksanaan Pembelajaran (RPP) selama proses pembelajaran dengan menggunakan perangkat pembelajaran yang dikembangkan (3) Mendeskripsikan Hasil belajar siswa setelah mengikuti kegiatan pembelajaran IPA materi suhu dan kalor (4) Motivasi siswa setelah menggunakan model pembelajaran IPA inkuiri terbimbing dengan strategi motivasi ARCS.

Penelitian ini diharapkan dapat menghasilkan suatu perangkat pembelajaran yang dapat meningkatkan mutu pembelajaran IPA. Secara rinci manfaat penelitian adalah sebagai berikut: (1) Bagi guru diharapkan dapat menjadi acuan yang benar bagi guru SMP pada 
umumnya dan guru IPA khususnya untuk memanfaatkan perangkat pembelajaran IPA model inkuiri terbimbing dengan strategi motivasi ARCS untuk meningkatkan hasil belajar siswa SMP. (2) Bagi siswa diharapkan dapat tercipta suasana belajar yang aktif, inovatif, kreatif, menyenangkan.

\section{METODE PENELITIAN}

Penelitian ini termasuk penelitian pengembangan, karena mengembangkan perangkat pembelajaran IPA model inkuiri terbimbing dengan strategi motivasi ARCS untuk meningkatkan hasil belajar siswa SMP yang meliputi Rencana Pelaksanaan Pembelajaran (RPP), Lembar Kegiatan Siswa (LKS), Buku Ajar Siswa (BAS) Materi Suhu dan Kalor, instrumen penilaian Hasil Belajar Siswa dan angket motivasi siswa. Pengembangan perangkat pembelajaran berorientasi pada 4-D (Four D Model) yang terdiri dari empat tahap (Thiagarajan, et.al.,1974). Implementasi model tersebut dalam penelitian ini hanya mencakup tiga tahap, yang meliputi Pendefenisian (Define), Perancangan (Design), dan Pengembangan (Develop), dimana tahap ke-4 yaitu Penyebaran (Disseminate) tidak dilakukan. Pemlihan model ini karena model ini tersusun jelas dan sistematis. Hal tersebut dapat terlihat dari setiap tahap telah diuraikan diatas dengan jelas kegiatan apa saja yang harus dilakukan.

Uji coba perangkat dilakukan dengan menggunakan rancangan one-group pretest-posttest design, karena menggunakan satu kelompok tanpa ada kelompok pembanding. Uji coba perangkat dilakukan untuk melihat kesesuaian pembelajaran dan karakteristisk siswa dalam jumlah terbatas. Rancangan ini melibatkan satu kelompok yang diobservasi pada tahap pretest (O1) yang kemudian dilanjutkan dengan perlakuan tertentu (X) dan posttest (O2) (Sugiyono, 2014).

Teknik pengumpulan data dilakukan dengan validasi, observasi, pemberian tes, pemberian tes, pengisiian angket, dan dokumentasi. Instrumen penelitian yang digunakan dalam rangka pengembangan perangkat pembelajaran yaitu validasi perangkat pembelajaran, kepraktisan perangkat pembelajaran; pengamatan keterlaksanaan pembelajaran, aktivitas siswa, hambatan pembelajaran, motivasi siswa, keefektifan perangkat pembelajaran; hasil belajar siswa. Teknik analisis data yang digunakan deskriptif kuantitatf dan kualitatif.

\section{HASIL PENELITIAN DAN DISKUSI}

\section{A. Validasi Perangkat Pembelajaran}

Hasil pengembangan perangkat pembelajaran yang meluputi RPP, LKS, BAS, instrumen Penilaian dan angket motivasi siswa divalidasi oleh pakar dan diujicobakan uji coba I 12 siswa dan uji coba II 30 siswa. RPP berbasis inkuiri terbimbing dengan strategi motivasi ARCS untuk meningkatkan hasil belajar siswa SMP dikembangkan pada materi suhu dan kalor. Hasil rata-rata validasi untuk aspek format 3,13 dengan kategori valid, aspek isi sebesar 3,46 dengan kategori valid dan rata-rata skor asek bahasa 3,50 dengan kategori valid. Instrumen lembar validasi RPP mempunyai rata- rata reliabilitas 93,16 RPP reliabel dan dapat digunakan.

LKS yang dikembangkan dari Hasil penilaian ratarata lembar kegiatan siswa untuk aspek format adalah 3,25 dengan kategori valid, rata-rata skor aspek isi 3,71 dengan kategori sangat valid dan untuk aspek bahasa dengan hasil rata-rata adalah 3,50 dengan kategori valid. Instrumen lembar validasi LKS rata-rata reliabilitas 94,03\% dan dapat dikatakan reliabel. BAS yang dikembangkan mempunyai rata-rata untuk aspek isi adalah 3,57 dengan kategori valid, rata-rata skor aspek penyajian 3,81 dengan kategori sangat valid,aspek bahasa rata-rata skor validasi 3,40 dengan kategori valid dan aspek fisik rata-rata skor 3,25 dengan kategori valid. Instrumen lembar validasi buku ajar mempunyai rata-rata reliabilitas $93,73 \%$ dikatakan reliabel. Hasil tersebut menunjukkan buku ajar yang dikembangkan valid untuk dijadikan buku panduan bagi siswa maupun guru dalam proses pembelajaran.

Instrumen Hasil Belajar terdiri dari hasil belajar aspek sikap, aspek pengetahuan dan aspek keterampilan. Rata-rata untuk sikap rasa syukur memperoleh skor dari aspek isi dan aspek bahasa masing-masing memperoleh skor 3 dengan kategori valid dan untuk sikap tanggung jawab dan jujur memperoleh skor 3 dari aspek isi dan bahasa dengan kategori valid. mempunyai rata-rata reliabilitas $100 \%$ dikatakan reliabel. Aspek pengetahuan rata-rata menunjukkan bahwa dari aspek isi perangkat ini mendapatkan skor 3,5 dan soal tes dinyatakan valid, dari aspek bahasa dan penulisan soal mendapatkan skor 3,0 dan dinyatakan valid. Rata-rata reliabilitas aspek isi $85,71 \%$ dan aspek bahasa dan penulisan $100 \%$. Aspek keterampilan untuk aspek isi adalah 3,88 dengan kategori sangat valid, rata-rata skor aspek konstruksi adalah 3,50 dengan kategori valid, aspek bahasa dengan skor rata-rata 3,50 dengan kategori valid, dan untuk aspek waktu memperoleh skor rata-rata 3,00 dengan kategori valid dan rata-rata reliabilitas $94,16 \%$ dan dapat dikatakan reliabel.

Angket Motivasi yang dikembangkan dari aspek isi, konstruksi, dan bahasa memperoleh rata-rata 3,5 dengan kategori valid. Reabilitas mencapai 85,7\%. Hasil tersebut menunjukkan lembar angket motivasi siswa yang dikembangkan valid untuk digunakan oleh guru. Berdasarkan uraian di atas dapat dikatakan bahwa perangkat pembelajaran yang dikembangkan dinyatakan layak untuk digunakan dalam proses pembelajaran pada materi suhu dan kalor. 


\section{B. Keterlaksanaan Perangkat Pembelajaran}

Tahapan kedua dalam penelitian ini, setelah perangkat pembelajaran divalidasi kemudian dilakukan ujicoba. Keterlaksanaan perangkat pembelajaran model inkuiri terbimbing dengan strategi motivasi ARCS yang diamati meliputi Pendahuluan, Kegiatan Inti, Penutup, Pengelolaan waktu, dan Suasana kelas. Hasil rekapitulasi keterlaksanaan RPP dapat dilihat pada Tabel 1 berikut:

Tabel 1. Keterlaksanaan RPP

\begin{tabular}{|l|l|c|c|}
\hline No & Aspek yang diamati & $\begin{array}{c}\text { Skor } \\
\text { rata-rata }\end{array}$ & Kategori \\
\hline 1. & Pendahuluan & 3,70 & Baik \\
\hline 2. & Kegiatan Inti & 3,71 & Baik \\
\hline 3. & Penutup & 3,73 & Baik \\
\hline 4. & Pengelolaan waktu & 3,50 & Baik \\
\hline 5. & Suasana kelas & 3,85 & Baik \\
\hline
\end{tabular}

Sintaks dalam RPP ini memuat langkah-langkah yang dirancang terlebih dahulu yang digunakan sebagai acuan dalam pelaksanaan pembelajaran yang sesungguhnya dikelas agar pelaksanaan kegiatan pembelajaran terarah sesuai dengan skenario pembelajaran yang dirancang dalam RPP. Pengamatan keerlaksanaan penggunaan perangkat pembelajaran dilakukan oleh dua orang pengamat dan dilakukan selama 5 kali pertemuan.

Berdasarkan hasil analisis dan deskripsi hasil pengamatan seperti terlihat pada Tabel 1 dapat dinyatakan bahwa seluruh tahapan pembelajaran terlaksana dengan kategori tiap aspek adalah baik dan skor rata-rata perolehan berada pada rentang 3,5-4,0 nilai reliabilitas rata-rata 96,33. Instrumen keterlaksanaan RPP dikatakan reliabel, apabila reliabilitasnya $\geq 75 \%$ (Borich, 1994). Hal ini menunjukkan bahwa instrumen keterlaksanaan RPP yang telah disusun memiliki konsistensi dalam mengukur keterlaksanaan RPP selama pembelajaran.

\section{Hasil Belajar Aspek Sikap}

Sikap siswa dalam pembelajaran diamati dengan menggunakan format yang berisi sejumlah indikator perilaku Aspek sikap yang diamati selama pembelajaran berlangsung. Hasil analisis aspek sikap siswa yaitu sikap religius dan sikap sosial. Sikap religius yang diamati selama pembelajaran adalah rasa syukur. Sikap sosial yang diamati dalam pembelajaran adalah tanggung jawab dan jujur. Sikap religius diambil dari nilai modus (nilai yang sering muncul) yang teramati dengan 30 siswa selama lima kali pertemuan memiliki modus dengan kategori sangat baik (Kemendikbud, 2014).

Sikap tanggung jawab dan sikap jujur yang teramati selama pembelajaran memiliki modus 4 dengan kategori sangat baik (Kemendikbud, 2014) hal ini menunjukkan bahwa dengan pembelajaran berbasis inkuiri terbimbing dengan strategi motivasi ARCS dapat mengembangkan sikap siswa kearah yang lebih baik, ini dikarenakan pembelajaran inkuiri merupakan proses pembelajaran perubahan tingkah laku karena adanya pengalaman yaitu pembelajaran yang dianggap sesuai dengan perkembangan psikologi belajar modern yang menganggap belajar (Sanjaya, 2006). Sebagai hasil belajar, bahan pengajaran berisi ranah kognitif, ranah afektif harus menjadi bagian integral dari bahan tersebut yang harus dimunculkan dalam proses pembelajaran (Bloom dalam Jufri, 2013). Hasil belajar afektif dalam penelitian ini tampak pada tingkah laku siswa yaitu sikap tanggung jawab dan jujur.

\section{Hasil Belajar Aspek Pengetahuan}

Hasil belajar berbasis inkuiri terbimbing dengan strategi motivasi ARCS digunakan untuk mengetahui tingkat penguasaan siswa atas materi pembelajaran. Tes hasil belajar dilakukan sebanyak dua kali yaitu sebelum pembelajaran (pretest) dan sesudah pembelajaran (posttest). Tes hasil belajar (aspek pengetahuan) terdiri dari 28 soal pilihan ganda.

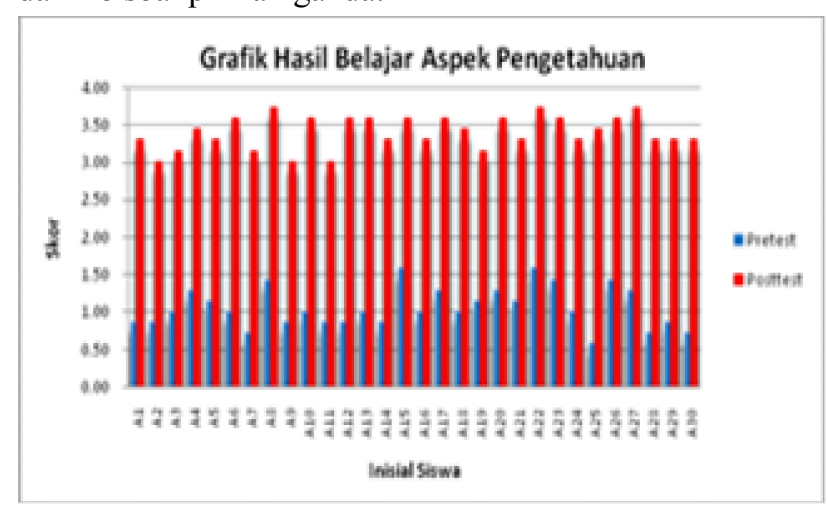

Gambar 1. Diagram Hasil Belajar Aspek Pengetahuan

Hasil belajar spek pengetahuan untuk ketuntasan Kompetensi dalam Kurikulum 2013 dituangkan dalam bentuk angka dan huruf, dalam menyekor pekerjaan siswa yakni untuk angka 4,00 - 1,00 yang ekuivalen dengan huruf A sampai D. Hasil belajar aspek pengetahuan ditetapkan dengan skor rerata 2,67 (Permendikbud 104, 2014).

Berdasarkan hasil yang diperoleh semua siswa tidak mencapai ketuntasan. Ketidaktuntasan siswa pada saat pretest disebabkan oleh belum dilaksanakannya pembelajaran pada materi yang diujikan, sehingga siswa masih belum paham dengan soal yang diujikan. Setelah dilakukan pembelajaran kemudian diberikan diperoleh posttest mencapai ketuntasan lebih baik dari hasil pretest. Peningkatan hasil belajar setelah dilakukan proses pembelajaran. Peneliti beranggapan hal-hal yang menyebabkan peningkaan hasil belajar, adalah motivasi siswa untuk belajar, serta keterlibatan siswa secara aktif dalam 
pembelajaran, khususnya kegiatan penyelidikan dengan bimbingan guru. Buku siswa juga memiliki peranan penting terhadap hasil belajar, buku siswa efektif dalam memandu siswa untuk belajar baik belajar di kelas maupun belajar mandiri.

Hasil belajar yang diperoleh merupakan perubahan tingkah laku siswa pada proses pembelajaran untuk mencapai tujuan dalam pembelajaran, perubahan tingkah laku tersebut mencakup aspek kognitif, afektif dan psikomotorik (Sudjana, 1991). Peningkatan yang ditunjukkan oleh hasil analisis dengan menggunakan $N$ Gain ini menunjukkan bahwa penerapan dari pengembangan perangkat pembelajaran IPA berbasis inkuiri terbimbing dengan strategi motivasi ARCS efektif dalam meningkatkan hasil belajar pada aspek pengetahun. Hal ini sesuai dengan Penelitian Madden (2011), menunjukkan pengggunaan inkuiri dapat membantu siswa menyimpan informasi kontekstual dan terbukti berhasil meningkatkan lingkungan belajar dan motivasi siswa.

Hal ini menunjukkan bahwa peningkatan hasil belajar siswa setelah diberikan perlakuan merupakan efek dari perlakuan pembelajaran berbasis inkuiri terbimbing dengan strategi motivasi ARCS. Pembelajaran dengan menggunakan model inkuiri terbimbing dengan strategi motivasi ARCS dapat meningkatkan hasil belajar kognitif siswa. Temuan ini sesuai dengan Penelitian Nwagbo (1997) (dalam Matthew \& Kenneth, 2013), Timoty dan Awodi (1997), dan Kurumeh (1999) (dalam Matthew \& Kenneth, 2013). Para peneliti ini menyimpulkan bahwa siswa yang diajar menggunakan pembelajaran inkuiri terbimbing mempunyai skor yang lebih baik dibandingkan siswa yang diajarkan dengan pembelajaran konvensional. Selain itu temuan ini konsisten dengan Astleitner \& Lintner (2004), strategi ARCS memiliki pengaruh positif pada saat memperoleh pengetahuan, proses pembelajaran dalam hal pengalaman dan keinginan belajar.

Berdasarkan uraian diatas maka dapat disimpulkan bahwa hasil belajar merupakan hasil yang diperoleh siswa setelah terjadinya proses pembelajaran yang ditunjukkan dengan nilai tes yang diberikan oleh guru setelah selesai memberikan materi pelajaran pada satu pokok bahasan suhu dan kalor.

\section{E. Hasil Belajar Aspek Keterampilan}

Tes kinerja (aspek keterampilan) yang dilakukan sebanyak dua kali yaitu sebelum (pretest) dan sesudah

pembelajaran (posttest). Aspek keterampilan dalam penelitian terdiri dari 8 indikator merumuskan hipotesis, mengidentifikasi variabel, melakukan percobaan/ pengamatan, menganalisis data/menjawab pertanyaan, membuat kesimpulan berdasarkan percobaan, mengukur volume cairan dengan gelas ukur, mengukur suhu dengan termometer, dan mengukur waktu dengan stopwatch.

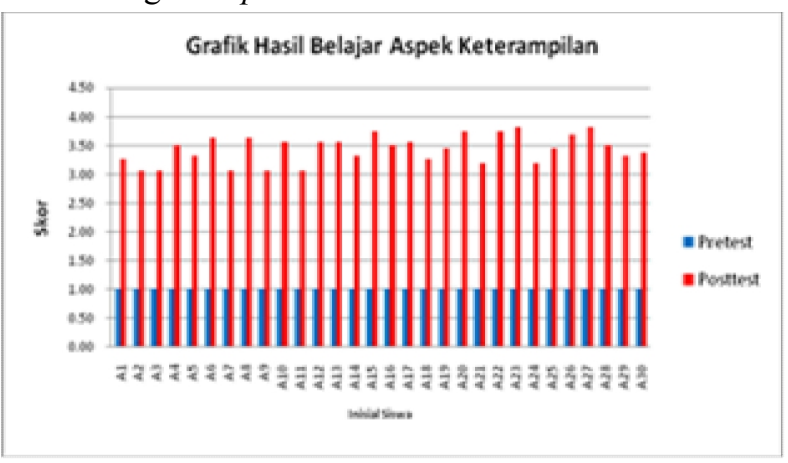

Gambar 2. Diagram Hasil Belajar Aspek Keterampilan

Berdasarkan hasil analisis dan deskripsi data hasil belajar aspek keterampilan diperoleh rata-rata 1,00 dan semua siswa tidak mencapai ketuntasan, rendahnya rata- rata skor ketuntasan pada saat pretest disebabkan siswa belum pernah melaksanakan pembelajaran dan kegiatan tes kinerja, siswa belum tahu menggunakan alat yang digunakan dalam tes kinerja. Hasil posttest setelah pembelajaran diperoleh skor rata-rata untuk aspek keterampilan 3,43. Peningkatan hasil belajar aspek keterampilan terlihat dengan $\mathrm{N}$-gain sebesar 0,81 dengan kategori tinggi (Hake, 1999). Peningkatan hasil belajar tes keterampilan ini dikarenakan sebelum pemberian tes kinerja selama 5 kali pertemuan adanya interaksi siswa dengan teman satu tim, siswa yang berkompoten dalam satu tim membantu temannya yang masih merasa kesulitan pada saat pembelajaran serta adanya bimbingan guru selama pembelajaran, siswa menjadi lebih terlatih dalam tes unjuk kerja sehingga siswa lebih termotivasi untuk menyelesaikan tugasnya. Keaktifan siswa sangat mempengaruhi dalam pembelajaran, siswa yang aktif dalam pembelajaran menunjukkan motivasi yang baik sehingga hasil belajar yang lebih tinggi, baik hasil pengetahuan maupun hasil belajar aspek keterampilan. Hal ini sesuai dengan pendapat Vygotsky (Slavin, 2011) penekanan hakekat sosiokultural dari pembelajaran, belajar secara bersama dapat membantu siswa dalam menguasai suatu konsep artinya seorang anak dalam menyelesaikan tugastugasnya tidak dapat melakukan sendiri, tetapi dapat melakukannya dengan bantuan teman sebaya atau orang dewasa yang lebih berkompenten.

Pembelajaran melalui proses inkuiri dapat mengoptimalkan keterlibatan langsung siswa atau pengalaman langsung dalam proses pembelajaran. Joyce, et al (dalam jufri, 2013). Hasil belajar yang diekspresikan dalam bentuk keterampilan menyelesaikan tugas-tugas manual dan gerakan fisik atau kemampuan bertindak disebut dengan Ranah psikomotor. Temuan ini sesuai dengan hasil penelitian Shih., Chuang, \& Hwang (2010) yang juga menemukan dalam hal kinerja belajar siswa, model inkuiri 
terbimbing selama pembelajaran dapat meningkatkan keterlibatan partisipasi fisik siswa dan afektif siswa. Hasil belajar dalam ranah ini juga mencakup aspek sosial seperti keterampilan berkomunikasi dan kemampuan mengoperasikan alat-alat tertentu. Hasil penelitian Maliyah, dkk (2012) menyimpulkan bahwa pendekatan inkuiri terbimbing menggunakan metode eksperimen dan demonstrasi berpengaruh terhadap prestasi kognitif, psikomotorik, dan afektif.

\section{F. Motivasi Belajar Siswa}

Motivasil siswa terhadap pembelajaran diperoleh dengan menggunakna angket motivasi siswa setelah proses pembelajaran selesai. Angket yang diberikan terdiri dari 36 item, yang meliputi 4 komponen yaitu perhatian siswa terhadap pembelajaran (attention), keterkaitan materi yang dipelajari dengan kebutuhan siswa (relevance), percaya diri siswa selama mengikuti pembelajaran (convidence), dan kepuasan siswa dalam mengikuti pembelajaran (satisfaction). Data tentang motivasi belajar siswa terhadap pembelajaran dapat dilihat pada Tabel 2 berikut:

Tabel 2. Hasil Motivasi Belajar Siswa

\begin{tabular}{|c|l|c|c|c|}
\hline No & \multicolumn{1}{|c|}{ Komponen } & Persentase & \multicolumn{2}{c|}{ Motivasi } \\
\cline { 4 - 5 } & Rata-rata & Kategori \\
\hline 2 & Attention (perhatian) & 84,56 & 4,20 & Baik \\
\hline 3 & $\begin{array}{l}\text { Relevance (keterkaiatan) } \\
\text { diri) }\end{array}$ & 82,92 & 4,06 & Baik \\
\hline 4 & Satisfaction (kepuasan) & 82,98 & 4,10 & Baik \\
\hline
\end{tabular}

Berdasarkan Tabel 2 analisis motivasi belajar siswa menunjukkan 4 komponen selama proses pembelajaran (Satisfaction) rata-rata dalam kategori baik. Peningkatan motivasi belajar siswa tersebut pada pembelajaran inkuiri terbimbing dengan strategi motivasi ARCS karena adanya motivasi-motivasi yang diberikan guru melalui aktivitas siswa dalam proses pembelajaran. Menurut Djamarah (2002), motivasi ialah pendorong dalam bentuk aktivitas nyata yang dapat mengubah energi diri seseorang agar dapat mencapai tujuan tertentu. Pemberian motivasi pada awal pembelajaran adalah salah satu cara untuk menarik perhatian siswa (Attention), dalam pemberian motivasi guru mengadakan Tanya jawab untuk menggali pengetahuan siswa. Tujuan pembelajaran yang terarah serta manfaat dari tujuan pembelajaran tersebut dalam kehidupan sehari-hari dan pertanyaan-pertanyan yang diberikan oleh guru dilakukan untuk memupuk rasa percaya diri siswa karena dengan tujuan pembelajaran yang jelas dapat mendorong rasa ingin tahu siswa dalam memahami materi pelajaran (Convidence).

Pembelajaran inkuiri terbimbing yang dikembangkan dapat memotivasi dengan strategi motivasi ARCS. Siswa merasa mendapatkan tantangan atau hal baru untuk menemukan konsep melalui percobaan, sehingga siswa terlihat sangat tertarik dan antusias mengikuti kegiatan pembelajaran. Hal ini sesuai dengan teori penemuan yang dikemukakan Bruner, dalam Slavin (2011) bahwa dengan pembelajaran penemuan siswa dituntut untuk menemukan sendiri prinsip-prinsip karena siswa didorong untuk belajar melalui keterlibatan aktif siswa untuk memperoleh pengalaman melalui eksperimen. Penggunaan alat dan bahan dalam percobaan yang jarang dijumpai dan digunakan siswa pada kegiatan pembelajaran sebelumnya, mampu menarik perhatian (Attention) dan rasa ingin tahu serta rasa percaya diri siswa untuk melakukan keterampilan secara mandiri (Convidence), sehingga siswa begitu antusias mengikuti kegiatan pembelajaran, walaupun ada siswa yang masih bermain dalam kegiatan percobaan. Pembelajaran inkuiri terbimbing dengan strategi motivasi ARCS juga dapat membuat pembelajaran terasa lebih bermakna bagi siswa karena pengalaman yang dimiliki siswa dalam percobaan dapat membantu mereka menghubungkan dan menjelaskan peristiwa yang terkait dalam kehidupan sehari-hari (Relevance). Agar siswa mampu menghubungkan pengalaman dari percobaan yang dilakukan dengan konsep yang ingin diajarkan, dengan kegiatan ini siswa akan merasa bahwa apa yang mereka pelajari benar-benar bermanfaat dan dapat diterapkan untuk menjelaskan peristiwa-peristiwa yang terjadi dalam kehidupan sehari-hari. Kegiatan yang dilakukan oleh siswa dalam mengumpulkan dan menganalisis data untuk membuktikan hipotesis yang telah dirumuskan sebelumnya juga dapat meningkatkan kepercayaan diri siswa untuk tampil di depan teman-temannya untuk menyampaikan hasil temuannya (Confidence).

Kegiatan diskusi yang dilakukan setelah percobaan, membuat siswa lebih percaya diri untuk menjawab dan menanggapi pertanyaan (bertanya atau menyampaikan pendapat), hal ini karena siswa mempunyai bukti fisik dari hasil percobaan yang dilakukannya berupa data hasil percobaan yang dapat menguatkan argumenargumen siswa dalam berdiskusi dan mengemukakan pendapatnya, jika hasil percobaan yang siswa lakukan sesuai dengan teori yang ada selain itu kegiatan diskusi bertujuan memberikan kemudahan pada siswa menguasai materi pelajaran melalui bantuan orang lain. Menurut Vygotsky (dalam Slavin, 2011) dengan belajar bersama atau berdiskusi dapat membantu siswa dalam menguasai suatu konsep. Vygotsky yakin bahwa pembelajaran baru akan terjadi apabila siswa belajar atau bekerja menangani suatu tugas secara bersama.

Pengalaman belajar siswa dengan percobaan atau pengamatan juga dapat meningkatkan kepuasan siswa terhadap kegiatan pembelajaran (Satisfaction). Siswa 
merasa puas terhadap pembelajaran yang telah dilakukan karena dalam memahami suatu konsep, siswa tidak hanya menerima informasi tetapi mereka mencari sendiri informasi, melakukan, dan membuktikan sendiri melalui percobaan. Hal ini sesuai dengan teori penemuan yang menyatakan membangkitkan keingintahuan siswa, dengan memotivasi mereka terus bekerja hingga siswa menemukan jawaban. Siswa juga mempelajari kemampuan menyelesaikan masalah dan pemikiran kritis secara mandiri, karena siswa harus menganalisis dan memanipulasi informasi (Slavin, 2011). Pengalaman belajar yang dimiliki siswa ini akan membuat siswa lebih mudah dalam memahami konsep yang diajarkan dan konsep tersebut akan melekat kuat dalam ingatan siswa. Selain itu, kegiatan diskusi yang dilakukan setelah percobaan yaitu membuat kesimpulan terhadap hasil yang diperoleh setelah percobaan, juga dapat meningkatkan kepuasan siswa, karena melalui diskusi tersebut siswa dapat memperoleh penguatan terhadap konsep yang mereka terima maupun menemukan solusi untuk hasil percobaan yang tidak sesuai dengan teori yang ada, selain itu upaya meningkatkan motivasi melalui penguatan dan pemantapan berupa penghargaan pada hasil kerja siswa (Satisfaction).

Siswa yang memiliki nilai tinggi pada angket motivasi sebagian besar memiliki rata-rata perhatian, ketertarikan, kepuasan, dan percaya diri yang baik. Hal ini disebabkan beberapa siswa merasa mampu dan bisa mengerjakan latihan-latihan pada LKS dan soal tes secara mandiri, ini terlihat pada tes hasil belajar siswa bahwa siswa yang mempunyai motivasi tinggi akan berdampak pada hasil belajarnya yang tinggi pula. Siswa akan menggunakan proses kognitif yang lebih tinggi dalam mempelajari informasi baru, apabila siswa termotivasi dalam belajar sesuatu, oleh karenanya siswa akan menyerap dan mengendapkan informasi baru itu lebih baik Garner dkk (1991) dan Graham \& Golan (1991) dalam (Nur, 2008).

Siswa akan belajar dengan baik bila ada faktor pendorongnya, yang disebut dengan motivasi. Siswa akan belajar dengan sungguh-sungguh apabila memiliki motivasi yang tinggi, tenaga pendorong dan penarik yang menyebabkan adanya tingkah laku kearah suatu tujuan tertentu disebut dengan motivasi Callahan dan Clark (dalam Mulyasa, 2011). Motivasi membuat siswa bergerak, menempatkan siswa dalam suatu arah tertentu, dan menjaga siswa agar terus bergerak Motivasi adalah sesuatu yang menghidupkan (energize), mengarahkan dan mempertahankan perilaku; Motivasi siswa tercermin dalam keterlibatan kognitif, emosional, dan perilaku diberbagai aktivitas sekolah Fredricks, Blumenfeld, \& Paris 2004; Maehr \& Meyer 2004, Reeve 2006 (dalam Ormrod, 2008).
Motivasi belajar siswa setelah mengikuti pembelajaran berbasis inkuiri terbimbing dengan strategi motivasi ARCS berdampak baik terhadap motivasi belajar siswa hal ini sesuai dengan pendapat Kulhthau (2007) bahwa inkuiri terbimbing merupakan pembelajaran yang memberikan kesempatan bimbingan kepada siswa untuk mengkontruksi pengetahuan siswa sendiri dan mengembangkan pemahaman yang terdalam dapat memotivasi siswa untuk belajar. Menurut National Research Council (dalam jauhar, 2011) tujuan inkuiri ada 3 yaitu: (1) Memotivasi dan mengembangkan keinginan siswa untuk mempelajari prinsip dan konsep, (2) Mengembangkan keterampilan ilmiah siswa sehingga mampu bekerja seperti layaknya seornag ilmuan, dan (3) Membiasakan siswa bekerja keras untuk memperoleh pengetahuan.

Penelitian ini sesuai dengan penelitian Astleitner \& Koller (2006), menyimpulkan bahwa strategi ARCS dapat meningkatkan efektivitas motivasi dan pembelajaran kognitif dan didukung oleh penemuan Wagman (2005); Colakoglu \& Akdemir (2010) bahwa inkuiri dapat mendukung motivasi siswa.

\section{G. Temuan Penelitian}

Temuan-temuan dalam penelitian ini adalah sebagai berikut:

1. Perangkat pembelajaran IPA model inkuiri terbimbing dengan strategi motivasi ARCS untuk meningkatkan hasil belajar siswa yang telah dikembangkan dinyatakan valid dan dapat digunakan dalam kegiatan pembelajaran IPA.

2. Keterlakasanaan RPP dengan 5 kali pertemuan dalam proses pembelajaran dengan secara rata-rata keseluruhan skor keterlaksanaannya berkategori baik.

3. Penerapan perangkat pembelajaran IPA model inkuiri terbimbing dengan strategi motivasi ARCS dapat mengembangkan aspek sikap siswa. Ketercapaian aspek sikap religius dan sikap sosial memperoleh rata-rata modus dengan kategori sangat baik dan baik.

4. Penerapan perangkat pembelajaran IPA model inkuiri terbimbing dengan strategi motivasi ARCS dapat meningkatkan hasil belajar siswa, yaitu ratarata $N$-gain sebesar 0,79 dengan kategori tinggi.

5. Penerapan perangkat pembelajaran IPA model inkuiri terbimbing dengan strategi motivasi ARCS dapat meningkatkan hasil belajar aspek keterampilan siswa. Peningkatan aspek keterampilan dapat dilihat dari $N$-gain yaitu 0,81 dengan kategori tinggi.

6. Motivasi siswa selama pembelajaran inkuiri terbimbing dengan strategi motivasi ARCS dikategorikan baik rata-rata di atas 4,00. 
7. Siswa dengan motivasi yang baik akan berpengaruh terhadap hasil belajarnya dengan nilai yang baik pula atau dengan kata lain motivasi belajar akan berpengaruh terhadap hasil belajar siswa.

\section{KESIMPULAN}

\section{A. Simpulan}

Berdasarkan temuan diatas dapat dibuat kesimpulan bahwa perangkat pembelajaran IPA model inkuiri terbimbing dengan strategi motivasi ARCS yang dikembangkan layak digunakan untuk meningkatkan hasil belajar siswa SMP.

\section{B. Saran}

Pengenalan awal model pembelajaran yang diterapkan bisa dilakukan pada waktu khusus, agar saat proses pembelajaran siswa tidak kesulitan menyelesaikan LKS dan melakukan penyelidikan. Penerapan rencana pelaksanaan pembelajaran sudah baik namun guru harus lebih dapat mengelola waktu selama pembelajaran agar pembelajaran bisa berjalan lebih efektif dan efisien.

\section{REFERENSI}

Arends, R. I. (2008). Learning To Teach, diterjemahkan oleh Helly Prajitno Soetjipto, Sri Mulyantini Soetjipto. Edisi VII Jilid 1. Yogyakarta: Penerbit Pustaka Pelajar.

Astleitner, H. \& Koller, M. (2006). "An AptitudeTreatment-Interaction-Approach on Motivation and Student's Self-Regulated MultimediaBased Learning." Journal Department of Educational Research Akademiestrasse. Austria: University of Salzburg. No.13, pp. 11-23.

Astleitner, H. \& Lintner, P. (2004). "The Effects Of Arcs-Strategies on Self-Regulated Learning With Instructional Texts". e-Journal of Instructional Science and Technology. Austria: University of Salzburg. Vol.7 No.1.

Banchi, H. \& Bell, R. (2008). The Many Levels of Inquiry. Science and Children. Vol.46 No.2, pp. 26-29.

Borich, G. (1994). Observation skill for effective teaching. New York: Mac Millan Publishing Company.

Borich, G. D. \& Choo, O. A. (2006). Teaching Strategies that Promote Thinking, Models and Curriculum Approaches. McGraw-Hills: Eeducation Asia.

Colakoglu, O.M \& Akdemir, O. (2010). "Motivational Measure of The Instruction Compared: Instruction Based on the ARCS Motivation Theory V.S. Traditional Instruction in Blended Courses". Turkish Online Journal of Distance
Education-TOJDE Vol.11 No.2, pp. 73-87.

Djamarah, S \& Zain. (2002). Strategi Belajar Mengajar. Jakarta: Rineka Cipta.

Hake. (1999). Analyzing change/gain scores. (Online). Tersedia http://www. physicsindiana.edu/sdi/Analyzing-ChangeGain. pdf.

Jauhar, M. (2011). Implementasi PAIKEM dari Behaviorristik sampai Konstruktivistik. Jakarta: Prestasi Pustaka.

Jufri, A. Wahab. (2013). Belajar dan Pembelajaran Sains. Bandung: Pustaka Reka Cipta.

Kardi, S. (2012). Pengantar Pengembangan Kurikulum dan Rencana Pelaksanaan Pembelajaran. Surabaya: Universitas Negeri Surabaya.

Keller, J.M. (1987). "Development and Use of the ARCS Model of Intructional Dsign". Jurnal of Instructiuonal Development. Florida: Florida State University Tallahased. Vol. 10 No.3 pp.29.

Kemendikbud. (2014a). Peraturan Menteri Pendidikan dan Kebudayaan No. 58 Tahun 2014 tentang Kurikulum 2013 Sekolah Menengah Pertama/Madrasah Tsanawiyah. Jakarta: Kemendikbud.

Kemendikbud. (2014b). Peraturan Menteri Pendidikan dan Kebudayaan No. 103 Tahun 2014 tentang Pembelajaran pada Pendidikan Dasar dan Pendidikan Menengah. Jakarta: Kemendikbud.

Kuhlthau. C.C., Leslie. K. Maniotes, and Ann. K. Caspari. (2007). Guided Inquiry: Learning in the $21^{\text {st }}$ Century School. Amerika: Libraries Unlimitied, inc.

Madden, K. R. (2011). "The Use Of Inquiry-Based Instruction To Increase Motivation And Academic Success In A High School Biology Classroom." Sience Education. Montana: Montana State University.

Maliyah, N., Sunarno, W., Suparmi. (2012). "Pembelajaran Fisika dengan Inkuiri Terbimbing Melalui Metode Eksperimen dan Demonstrasi Diskusi ditinjau dari Kemampuan Matematik dan Kemampuan Verbal Siswa". Jurnal Inkuiri. Vol.1 (3), pp, 227-234.

Matthew \& Kenneth, (2013). "The Effects of guided inquiry teaching method on students achievenment in logic". Journal Internasional Researcher. Vol.2 No.1, pp 135.

Mukhlasin. (2011). Pembelajaran Perangkat Pembelajaran IPA-Fisika SMP Pokok Bahasan Cahaya Berorientasi pada Model pembelajaran penemuan Terbimbing dan Menerapkan Strategi Motivasi ARCS. Tesis magister tidak dipuplikasikan. Surabaya.: Unesa. 
Mulyasa, E. (2013). Kurikulum Tingkat Satuan Pendidikan Suatu Panduan praktis. Bandung: PT Remaja Rosdakarya.

Nur, M. (2008). Pemotivasi Siswa Untuk Belajar. Cetakan Ketiga. Surabaya: Pusat Sains dan Matematika Sekolah, Universitas Negeri Surabaya.

Ormrod, J. E. (2008). Psikologi Pendidikan Edisi Keenam. Jakarta: Penerbit Erlangga.

Sanjaya, W. (2006). Strategi Pembelajaran Berorientasi Standar Proses Pendidikan. Jakarta: Kencana.

Sanjaya, W. (2011). Perencanaan dan Desain Sistem Pembelajaran. Jakarta: Kencana.

Shih, J. L., Chuang, C. W., \& Hwang, G. J. (2010). “An inquiry-based mobile learning approach to enhancing social science learning effectiveness". Journal Educational Tecnology \& Society. Vol.13 (4), 2010 pp 50-62.

Slavin, R.E. (2011a). Psikologi Pendidikan: Teori dan Praktik Edisi Kesembilan Jilid I. Jakarta: Indeks.

Slavin, R.E. (2011b). Psikologi Pendidikan: Teori dan Praktik Edisi Kesembilan Jilid II. Jakarta: Indeks.

Sudjana, N. (1991). Penilaian Hasil Proses Belajar Mengajar. Bandung: Rosdakarya.

Sugiyono. (2014). Metode penelitian kombinasi (mixed methods). Bandung: ALFABETA.

Thiagarajan, S. Semmel, Dorothy S, Semmel, M. I. (1974). Intructional Development for Training Teachers of Exceptional Children. Washington, DC: National Center for Improvement Educational.

Uno, B. H. (2012). Teori Motivasi dan Pengukurannya: Analisis di Bidang Pendidikan. Jakarta: PT Bumi Aksara.

Wagman, J.C. (2005). The Effects of an InquiryInternet Research Project on Motivation, SelfEfficacy, and Academic Autonomy in Heterogenously Grouped High School Latin Students (Unpublished doctoral dissertation). Capella University.

Widodo, W., Suryanda, A., Cahyana, U., Rachmadiarti, F., Hidayati, S.N., Kistina, I., Anifah, A., \& Suryatin, B. (2014). Buku Guru Ilmu Pengetahuan Alam SMP/MTs Kelas VII. Jakarta: Kementerian Pendidikan dan Kebudayaan.

Wulandari, A.D., Kurnia.. \& Sunarya, Y. (2013). "Pembelajaran Praktikum Berbasis Inkuiri Terbimbing untuk Meningkakan Keterampilan Berpikir Kritis Siswa SMA pada Materi Laju Reaksi”. Jurnal Riset dan Praktik Pendidikan Kimia. Vol.1 No.1 pp. 18-26. 